\title{
Using Selected Types of Waste to Produce New Light Ceramic Material
}

\author{
Anna Gronba-Chyła ${ }^{1 *}$, Agnieszka Generowicz ${ }^{2}$, Agnieszka Kramek ${ }^{3}$ \\ ${ }^{1}$ The John Paul II Catholic University of Lublin, Faculty of Engineering and Technical Sciences in Stalowa Wola, \\ ul. Kwiatkowskiego 3a, 37-450 Stalowa Wola, Poland \\ ${ }^{2}$ Cracow University of Technology, Department of Environmental Technologies, \\ ul. Warszawska 24, 31-155 Cracow, Poland \\ ${ }^{3}$ Rzeszow University of Technology, Department of Mechanics and Technology, \\ ul. Kwiatkowskiego 4, 37-450 Stalowa Wola, Poland
}

Received: 29 May 2020

Accepted: 18 August 2020

\begin{abstract}
The article presents research on the possibility of using troublesome waste such as: sewage sludge, mineral fraction of municipal waste $<10 \mathrm{~mm}$, stabilizer after mechanical-biological processing (MBP), carbon waste, glass - as a flux in the production of new light ceramic materials. Clay was used as the basis of the material. In order to determine the possibility of using individual materials to produce a ceramic material, the oxide composition of individual components was examined using the XRF method. XRF analysis showed the presence of quartz and aluminosilicates in the materials, which makes it possible to use these wastes to produce new materials. Then the waste was ground in a ball mill and mixed in different proportions by adding water and three different materials were obtained. Material A: clay, sewage sludge, waste water, glass. Material B: clay, mineral fraction of waste $<10 \mathrm{~mm}$, flotation waste, glass. Material C: clay, stabilizer after mechanical-biological processing, post-mining waste, glass. The materials were subjected to strength and absorbability tests. The most stable was Material B. The highest variability of properties was observed in Material A. On the other hand, a high heterogeneity was observed in Material C. The bulk density for all materials was $658 \mathrm{~kg} / \mathrm{m}^{3}$ on average.
\end{abstract}

Keywords: circular economy, waste, sewage sludge, mineral fraction of municipal waste $<10 \mathrm{~mm}$, stabilizer after mechanical-biological processing (MBP)

\section{Introduction}

Circular economy is a concept aimed at rational use of resources and reduction of negative environmental impact of manufactured products. These, in turn,

*e-mail: amgronba@kul.pl should remain in the economy as long as possible, so that the production of waste is minimized. Reduction of waste generation, reuse and new products from waste materials are priorities of a circular economy. The EU legal tool supporting the transition to a circular economy is to be the so-called waste package, i.e. the amendment of 6 directives on waste management [1]. According to the European Commission, some sectors face particular challenges in the context of the circular economy, due 
to the characteristics of their products and value chains, their environmental footprint and often dependence on materials from outside Europe. According to official EU statistics, in 2014 the total amount of waste generated in EU countries by all economic sectors and households was 2.5 billion tonnes. This was the highest amount recorded between 2004 and 2014. Almost 35\% of this was waste from the construction sector. The mining and quarrying sector is responsible for another $28 \%$, industrial production for $10 \%$ and wastewater treatment for $9 \%$. Household waste is only the fifth largest waste stream in Europe, accounting for $8.3 \%$ of the total waste generated in Europe. The management of municipal waste will be particularly important as it is for this waste that the European Commission is proposing $65 \%$ recycling by 2035 . According to figures for 2014 , as much as $54 \%$ of municipal waste in the EU goes to landfill or thermal treatment. Only about $28 \%$ is recycled and another $16 \%$ composted. In the light of the above considerations, closing the circuits and reducing waste from the construction, mining and municipal sectors together with waste from sewage treatment plants will be a priority for the coming years [2-4].

Sewage sludge is a product of urban or industrial wastewater treatment plants. They are waste from group 19 [5] or others depending on the type of industry in which they are produced [6]. Until now, they have been successfully used in agriculture as a fertilizer [7], currently more and more restrictive legal regulations prohibit the use of this waste in this way [8]. It is also impossible to store them. This encourages the search for new ways to use it, taking into account its possible qualitative composition [9]. One of them is the incineration of sludge with energy recovery or pyrolysis $[10,11]$ but this is an expensive solution. Use of sewage sludge in cement production as a co-fuel [12].

Also, other waste streams, e.g. coal, representing $50 \%$ of the generated waste [13] and flotation need new solutions and applications. Most of them are used in accordance with the law only as fillers for unfavorably transformed areas [14, 15].

As a result of the processing of municipal waste subjected to mechanical-biological treatment, there remains a stabilization for which there is currently no idea of further development [16]. The mineral fraction $<10 \mathrm{~mm}$ from municipal waste is rarely considered a potential raw material [17], it is rather treated as burdensome, difficult to manage waste. For these wastes mixing with other materials in appropriate proportions and producing new products seems to be the best solution.

The above mentioned wastes have numerous applications and possibilities of use in such a way as to reduce their stream or harmful character. Merino [18] has studied the ceramic properties of sludge ashes, alone or mixed with additives (kaolin, montmorillonite, ilolithic clay, powdered flat glass). Prepared samples with different proportions of components were mixed dry and wet and subjected to thermal treatment at $1200^{\circ} \mathrm{C}$. Then they were checked for compressive strength, density and water adsorption. Ravindra [19] noted that the addition of ground glass can act as a flux to lower the firing temperature during the ceramic manufacturing process and reduce the leaching of hazardous components by inerting. The paper [20] presents a methodology in which dry sewage sludge (DSS) was mixed as the main material with carbon ash (CA) to produce lightweight aggregates. The use of DSS improved the pyrolysis-stacking reaction due to the high content of organic matter and reduced the bulk density and sintering temperature. Sinter products of unmodified DSS were porous and loose due to the formation of large pores during sintering. The addition of CA improved the sintering temperature, while effectively reducing the size of the pores and increasing the product's compressive strength. Mazela [21] investigated that it is possible to vitrify sewage sludge, silica waste and waste glass together at $1100^{\circ} \mathrm{C}$. The thermal synthesis resulted in a material that meets the standards for artificial aggregates. These studies indicate the results of replacing clay with sewage sludge in various proportions in the ceramic body [22]. Bricks were produced with the addition of sewage sludge in the amount of 10 to $40 \%$ of dry matter. The texture and surface finish of clay bricks with the addition of sewage sludge were rather weak. In terms of physical and chemical properties, bricks with sewage sludge content up to $40 \%$ of mass were able to meet the relevant technical standards. However, bricks with a sludge content of more than $30 \%$ by weight are not recommended [23]. The use of sludge, furnace slag and fly ash in the production of clay bricks. Waste materials were added to bird clay at a rate of $5 \%, 10 \%$, $15 \%$. 10 different mixtures with different proportions of waste materials were produced. The sewage sludge has a negative impact on the strength of the bricks. [24]. Latosińska [25] demonstrated that sewage sludge in a $5-20 \%$ share can be used as bulking material. Their presence allows to lower the firing temperature and the share of clay in the mixture reduces the emission of pollutants. Alternative lightweight aggregates were also obtained by mixing waste components: hydrated sludge containing certain amounts of combustible components, waste silica dust from the production of aggregates with a significant content of silica, crushed glass waste [26]. There are also known patents: synthetic aluminosilicate aggregates [26, 27] - combinations of aluminosilicates with low and high calcium content are used, construction elements are produced [26, 28] - sewage sludge is combined with natural clay, foamed aggregate is produced [26, 29]- firing of a mixture of raw clay or conifer shale with dehydrated sewage sludge at $2000^{\circ} \mathrm{C}$ in a rotary kiln, production of lightweight aggregates [26, 30] - creation of so-called "pellets" from sewage sludge and volatile dust from the combustion and sintering processes in a rotary kiln. Wójcik [31] in laboratory tests, unconventional material derived from sewage sludge, glass powder and quartz 
sand were achieved. Haiying [32] used fly ash from the incineration of municipal solid waste (MSWI) as a mix to produce ceramic bricks based on its characteristics. In addition, the fired bricks made according to the optimal mix ratio were characterized in terms of efficiency, phase transformation, microstructure, heavy metal leaching toxicity according to standards, XRD and SEM analysis methods and leaching toxicity. Li Zanga et al. discussed the effect of asbestos waste content and sintering temperature on the phase composition, microstructure and properties of porous glass ceramics and explained the mechanism of pore formation [33]. Two waste materials from brick production, brick rubble and brick microparticles, initially in terms of chemical and mineralogical composition, together with the characteristics of the brick body itself, were examined. In the next stage, they were used in various doses as bulk fillers for modified brick blocks [34]. Mahieux [35] compared two methods of testing the mineral composition of ash from sewage sludge and fly ash from solid waste incineration: based on calculations using qualitative mineralogical composition of waste in combination with physicochemical analyses and the Rietveld method. The latter method uses only X-ray diffractograms. The results obtained are consistent, showing that it is possible to quantify the mineral composition of complex mineral wastes using such methods. Gronba [36] indicate, in the XRD analysis of municipal sewage sludge, three main phases: calcite, quartz, dolomite. This leads to the conclusion that sludge can be used to produce lightweight aggregates.

The aim of this article is to present the use of clay as a base material and waste: sewage sludge, stabilization after mechanical-biological processing, mineral fraction $<10 \mathrm{~mm}$ from municipal waste, post-flotation waste from coal and glass from municipal waste to produce new material. This will allow for the reduction of the quantitative stream, reduction of storage and related environmental loads and production of new material. This will reduce the amount of waste to be landfilled, thus saving space on the final waste dump and producing new material, while saving natural resources. This is consistent with the concept of circular economy. The article will present the possibilities of mixing these types of waste, thus creating a new product, whose properties must guarantee the possibility of its use.

\section{Methods and Material}

\section{Proposals for the Use of Waste - the Purpose of Research}

The following methodology has been proposed to achieve the objective:

- selection and examination of the properties of the selected waste groups in terms of their potential use for the production of new material - analyses XRF,
- choosing the right mixes for the production of new material - based on the collected literature.

- creating a new product and testing its properties for use as lightweight construction ceramics.

The following were selected for the study: till clay, sewage sludge, mineral fraction $<10 \mathrm{~mm}$ coming from processing in municipal waste installations, stabilizer after mechanical-biological processing, post-flotation waste from coal mines, glass from selective collection from inhabitants. With respect to the collected literature, attempts were made to manage clay sewage sludge in new ceramic materials. However, there is no literature on attempts to utilise the mineral fraction of waste $<10 \mathrm{~mm}$ or stabiliser (MBP).

\section{Methods and Materials - Research Methodology}

\section{Sampling of Waste and Additives - Identification of Qualitative and Quantitative Composition}

The research used wastes and additives, commonly available for a selected region - Stalowa Wola (till clay, cullet) and those that cause problems in disposal and recycling (sewage sludge, mineral fraction, stabilizer after mechanical-biological processing, flotation waste from the processing of charcoal). All components were analysed with XRF WDX spectrometer to determine the composition of individual materials. XRF analyses showed the presence of quartz and aluminosilicates in the waste to give the possibility to use the waste in building ceramics. The results are presented below in tables.

Dumping clay - used as a base material for the created material. This clay originates from the Quaternary and is found on Miocene clays [37] and is commonly used for brick making. From the analysis one can read the dominance of mainly four oxides: silicon, aluminium, iron and calcium. The results are presented in Table 1.

Sewage sludge - hygienized, taken from the sewage treatment plant in Stalowa Wola. Containing on average $84 \%$ of water [38]. XRF WDX analyses show the highest content of calcium oxide, phosphorus and silicon, iron, sulphur, manganese and aluminium oxide are found in smaller amounts. The results are presented in Table 2.

Mineral fraction of municipal waste $<10 \mathrm{~mm}-$ originated from mixed municipal waste and obtained from the winter season $[39,40]$. According to the analyses carried out, it contains the greatest amount of oxides of silicon, calcium, sodium, aluminium and iron. The results are presented in Table 3 .

Stabilizer (MBP) - received after mechanicalbiological treatment of waste (MBP) obtained from the Regional Municipal Waste Treatment Plant. The composition is dominated by oxides of silicon, calcium and aluminium. The results are presented in Table 4.

Post-flotation waste - containing on average about $50 \%$ of coal, taken from the "Murcki-Staszic" charcoal 
Table 1. XRF WDX analysis for clay.

\begin{tabular}{|c|c|c|c|c|c|c|c|c|c|c|c|c|}
\hline Composition & $\mathrm{SiO}_{2}$ & $\mathrm{Al}_{2} \mathrm{O}_{3}$ & $\mathrm{Fe}_{2} \mathrm{O}_{3}$ & $\mathrm{CaO}$ & $\mathrm{K}_{2} \mathrm{O}$ & $\mathrm{MgO}$ & $\mathrm{Na}_{2} \mathrm{O}$ & $\mathrm{Ti}$ & $\mathrm{SO}_{3}$ & $\mathrm{P}_{2} \mathrm{O}_{5}$ & $\mathrm{Mn}$ & $\mathrm{Ba}$ \\
\hline Content in \% & 60,6 & 17,8 & 6,63 & 6,57 & 3,62 & 2,8 & 0,65 & 0,54 & 0,32 & 0,264 & 0,12 & 0,04 \\
\hline
\end{tabular}

Table 2. XRF WDX analysis for sewage sludge.

\begin{tabular}{|c|c|c|c|c|c|c|c|c|c|c|c|c|}
\hline Composition & $\mathrm{CaO}$ & $\mathrm{Pa}_{2} \mathrm{O}$ & $\mathrm{SiO}_{2}$ & $\mathrm{Fe}_{2} \mathrm{O}_{3}$ & $\mathrm{SO}_{3}$ & $\mathrm{MgO}$ & $\mathrm{Al}_{2} \mathrm{O}_{3}$ & $\mathrm{~K}_{2} \mathrm{O}$ & $\mathrm{Na}_{2} \mathrm{O}$ & $\mathrm{TiO} 2$ & $\mathrm{ZnO}$ & $\mathrm{Cl}$ \\
\hline Content in \% & 38,81 & 20,36 & 14,1 & 6,52 & 5,85 & 5,73 & 4,51 & 1,96 & 0,72 & 0,64 & 0,22 & 0,17 \\
\hline
\end{tabular}

Table 3. XRF WDX analysis for mineral fraction of municipal waste $<10 \mathrm{~mm}$ of the winter. season.

\begin{tabular}{|c|c|c|c|c|c|c|c|c|c|c|c|c|}
\hline Composition & $\mathrm{SiO}_{2}$ & $\mathrm{CaO}$ & $\mathrm{Na}_{2} \mathrm{O}$ & $\mathrm{Al}_{2} \mathrm{O}_{3}$ & $\mathrm{Fe}_{2} \mathrm{O}_{3}$ & $\mathrm{MgO}$ & $\mathrm{K}_{2} \mathrm{O}$ & $\mathrm{SO}_{3}$ & $\mathrm{Cl}$ & $\mathrm{P}_{2} \mathrm{O}_{5}$ & $\mathrm{TiO}_{2}$ & $\mathrm{ZnO}$ \\
\hline Content in $\%$ & 70,3 & 11,8 & 4,25 & 4 & 3,42 & 1,41 & 1,35 & 1,28 & 0,85 & 0,44 & 0,34 & 0,27 \\
\hline
\end{tabular}

Table 4. XRF WDX analysis for stabilizer after mechanical and biological processing of waste.

\begin{tabular}{|c|c|c|c|c|c|c|c|c|c|c|c|}
\hline Composition & $\mathrm{SiO}_{2}$ & $\mathrm{CaO}$ & $\mathrm{Al}_{2} \mathrm{O}_{3}$ & $\mathrm{SO}_{3}$ & $\mathrm{Na}_{2} \mathrm{O}$ & $\mathrm{MgO}$ & $\mathrm{Fe}_{2} \mathrm{O}_{3}$ & $\mathrm{~K}_{2} \mathrm{O}$ & $\mathrm{Cl}$ & $\mathrm{TiO}_{2}$ & $\mathrm{CuO}$ \\
\hline Content in \% & 73,7 & 9,3 & 5,4 & 3,4 & 2,01 & 1,68 & 1,2 & 1 & 0,9 & 0,8 & 0,5 \\
\hline
\end{tabular}

Table 5. XRF WDX analysis for post-flotation waste.

\begin{tabular}{|c|c|c|c|c|c|c|c|c|c|c|c|}
\hline Composition & $\mathrm{SiO}_{2}$ & $\mathrm{Al}_{2} \mathrm{O}_{3}$ & $\mathrm{Fe}_{2} \mathrm{O}_{3}$ & $\mathrm{~K}_{2} \mathrm{O}$ & $\mathrm{SO}_{3}$ & $\mathrm{MgO}$ & $\mathrm{CaO}$ & $\mathrm{Na}_{2} \mathrm{O}$ & $\mathrm{Ti}$ & $\mathrm{P}_{2} \mathrm{O}_{5}$ & $\mathrm{Cl}$ \\
\hline Content in \% & 22 & 11,8 & 1,82 & 1,37 & 0,83 & 0,8 & 0,76 & 0,27 & 0,25 & 0,15 & 0,13 \\
\hline
\end{tabular}

Table 6. XRF WDX analysis for glass from mixed municipal waste.

\begin{tabular}{|c|c|c|c|c|c|c|c|c|c|c|c|c|}
\hline Composition & $\mathrm{SiO}_{2}$ & $\mathrm{CaO}$ & $\mathrm{Na}_{2} \mathrm{O}$ & $\mathrm{Al}_{2} \mathrm{O}_{3}$ & $\mathrm{~K}_{2} \mathrm{O}$ & $\mathrm{MgO}$ & $\mathrm{Fe}_{2} \mathrm{O}_{3}$ & $\mathrm{CuO}$ & $\mathrm{SO}_{3}$ & $\mathrm{BaO}$ & $\mathrm{TiO}_{2}$ & $\mathrm{Cl}$ \\
\hline Content in $\%$ & 69,9 & 15,6 & 9,44 & 1,77 & 1,33 & 0,94 & 0,31 & 0,19 & 0,15 & 0,07 & 0,05 & 0,05 \\
\hline
\end{tabular}

mine. The XRF analysis (after deduction of coal) shows the highest content of silicon, aluminium oxides. The results are presented in Table 5.

Glass - unwashed, from segregated waste from the installations/from the residents. XRF WDX analysis shows the highest content of silicon, calcium and sodium oxides. The results are presented in Table 6 .

\section{Preparation of Samples of Different Mixtures for Preparing Waste Aggregates}

In order to unify the morphological structure of the mixture: clay, sewage sludge, mineral fraction, stabilizer, post-flotation waste and glass were made:

- drying of all taken materials in appropriate proportions due to different water content in their structures. The materials were placed in a laboratory dryer and dried at $105.5^{\circ} \mathrm{C}$ for 12 hours,

- in order to unify and shredding the materials and make it easier to weigh and select the proportions, the individual materials were milled successively in the following mills: disc Pulverisette 13 then monoplanetary Pulverisette 6,

- the previously described mixture components were mixed in the Pulverisette 6 mono-planetary mill in appropriate proportions dividing it into three groups: Material A, Material B, Material C, each of six tests. The grouping for the creation of a new product was based on the amount of predominant and variable waste in the composition in each sample: The predominant components in all materials were: clay, post-flotation waste, glass. Variables: sewage sludge, mineral fraction of municipal waste $<10 \mathrm{~mm}$, stabilizer after mechanicalbiological processing (MBP)

- Material A - base: clay, waste: mostly sewage sludge, others are post-flotation waste and glass,

- Material B - base: clay, waste: mostly, mineral fraction of municipal waste $<10 \mathrm{~mm}$, others are postflotation waste and glass,

- Material C - base: clay, waste: mostly stabilizer after mechanical-biological processing (MBP), others are post-flotation waste and glass. 
The proportions of individual samples are presented in Figs 1,2,3.

After dry mixing of the components in the tests, a sufficient amount of water was added to each test and stirred to produce a uniform cylindrical test material. Eight $20 \mathrm{~mm}$ long and $10 \mathrm{~mm}$ diameter cylindrical shaped specimens were formed for each test. The samples were dried in a laboratory dryer for 12 hours at

\section{Material A - proportions of the mixtures with sewage sludge as a predominant waste (sample no. 1-6)}

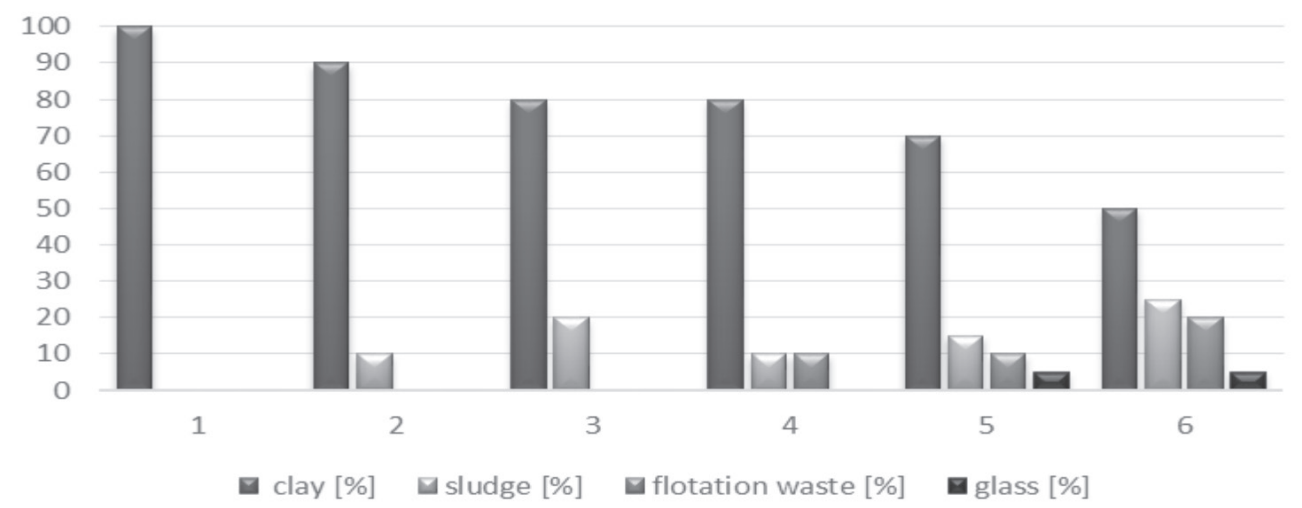

Fig. 1. Material A - proportions of the mixture with predominant waste: sewage sludge.
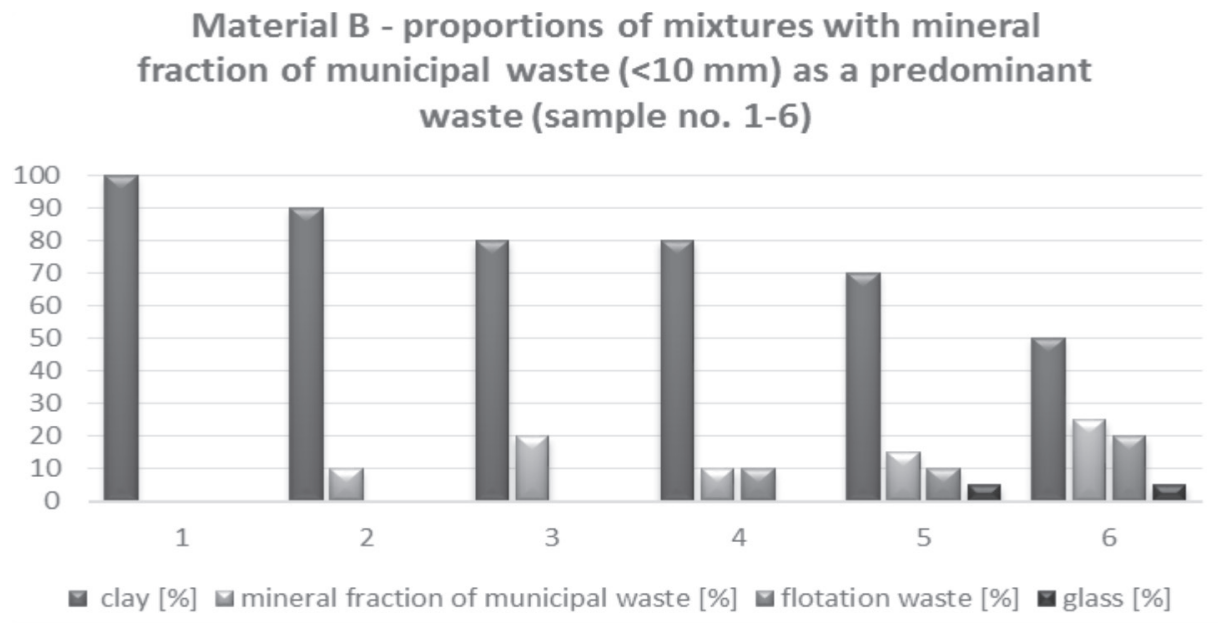

Fig. 2. Material B - proportions of mixtures with predominant waste: mineral fraction of municipal waste $<10 \mathrm{~mm}$.

\section{Material C - proportions of mixtures with stabilizer after mechanical-biological processing as a predominant waste (sample no. 1-6)}

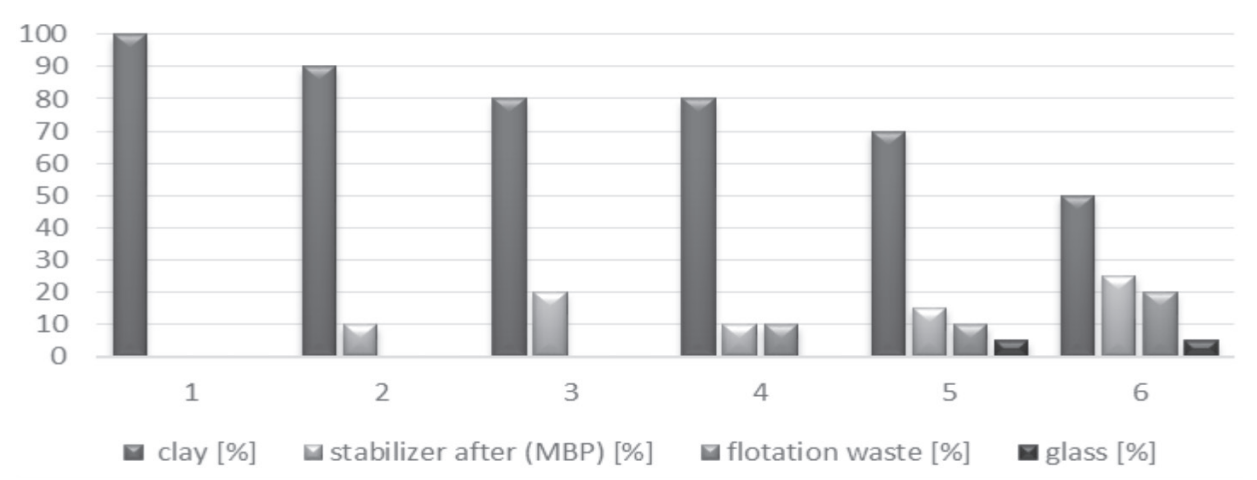

Fig. 3. Material C - proportions of mixtures with predominant waste: stabilizer after mechanical-biological processing. 

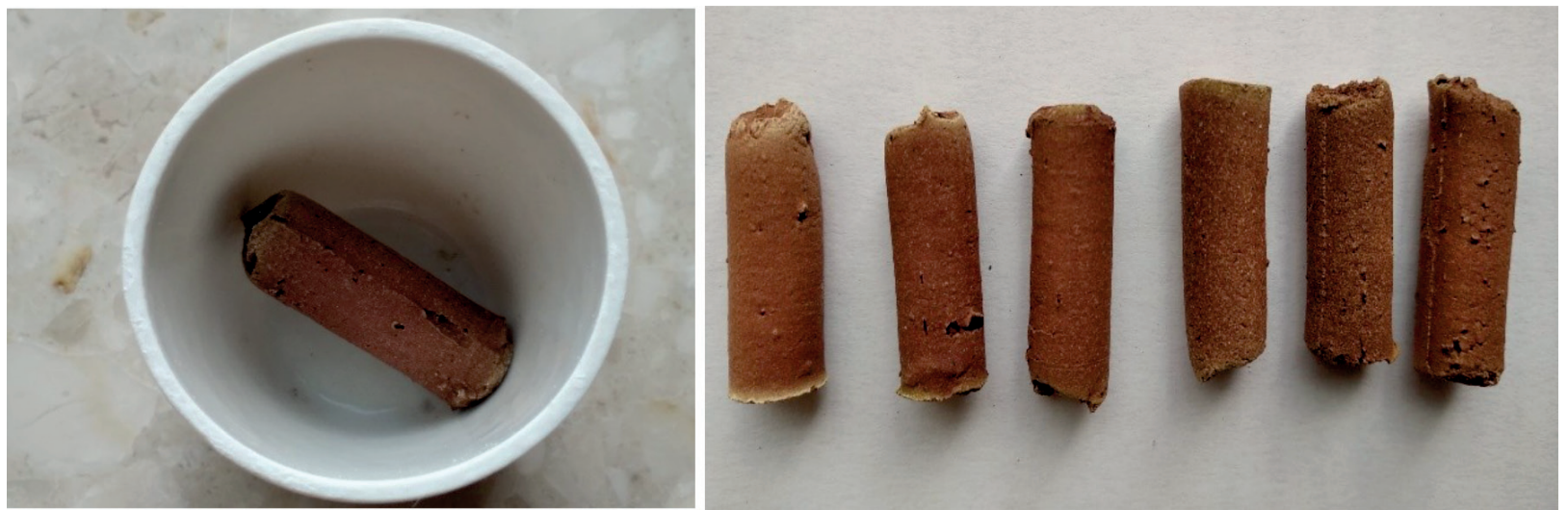

Fig. 4, 5. Samples after firing and cooling down.

$105.5^{\circ} \mathrm{C}$. After drying the samples were fired in a muffle furnace at $1100^{\circ} \mathrm{C}$ for 2 hours. This treatment was performed in order to bind structurally and molecularly clay particles with the remaining components. After firing the samples were cooled. Fig 4, 5, shows an example of a sample after firing and cooling down.

A new material has been obtained. It has the character of a building material - aggregates which can be used provided that the requirements for aggregates are met. The average bulk density loose for all materials was $658-728 \mathrm{~kg} / \mathrm{m}^{3}$. Use of them will allow the implementation of recycling and reduction of waste.

Then 5 samples from each test were subjected to strength testing on an Instrom testing machine. The specimen was crushed until the maximum load on the specimen's surface with a diameter of $10 \mathrm{~mm}$ was reached and the load force was measured (in Newton degrees). Fig. 6 below shows the strength test for one specimen.

The remaining 3 samples were subjected to a soaking test by soaking the samples daily in water then calculating the difference in the weight of the samples (cylinders). Below in Figs 7, 9, 11, was shown the average results of analyses for individual groups.

\section{Results and Discussion}

The aim of the research was to produce a new building material modelled on light ceramics from clay with the addition of waste from the following groups: sewage sludge, stabilizer after mechanical and biological processing, mineral fraction from municipal waste $<10 \mathrm{~mm}$, post-flotation waste from charcoal mines and glass. The new material must meet the quality requirements for it to be used and be in demand.

On the basis of XRF WDX and XRD analyses basic information was obtained concerning the particular composition of waste groups: sewage sludge, mineral fraction from municipal mixed waste and stabilizer after mechanical and biological treatment. Additionally, data characterizing these wastes were obtained in combination with other materials such as till clay, post-
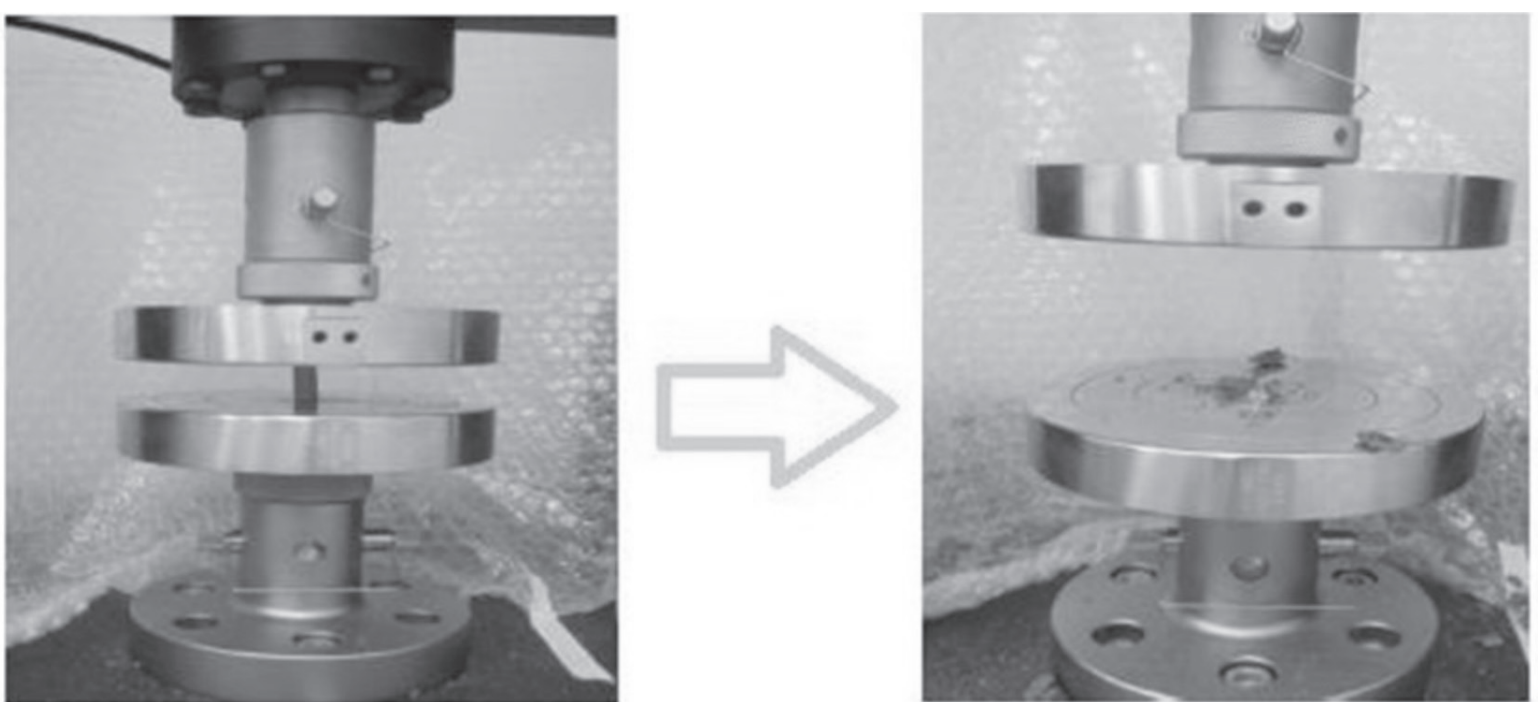

Fig. 6. Sample subjected to strength test [41]. 
Material A - compressive strength [MPa]

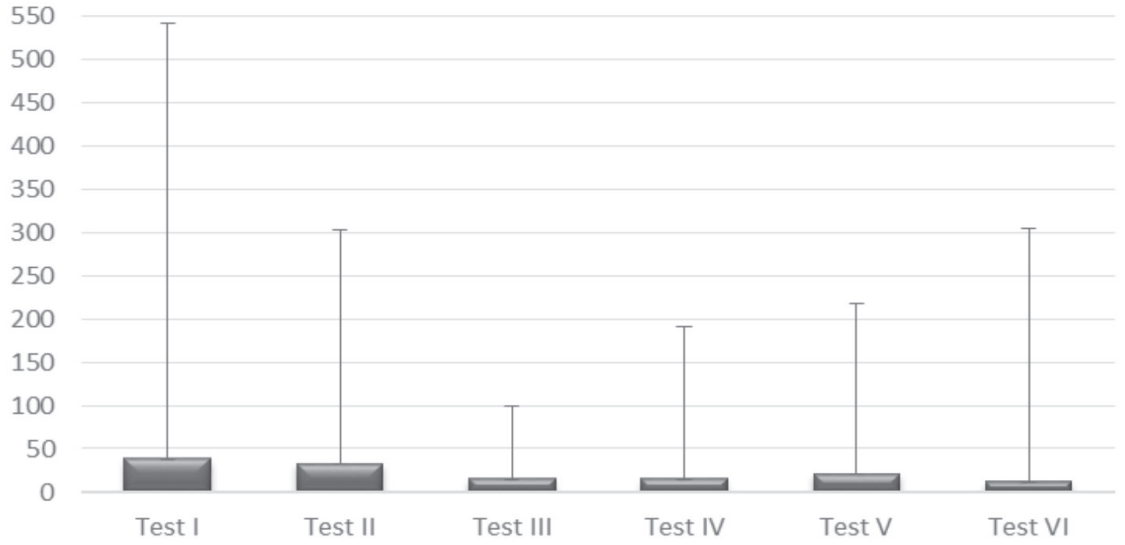

Fig. 7. Summary of average results for strength tests for Material A with predominant waste: sewage sludge.

Material A - water absorption [\%]

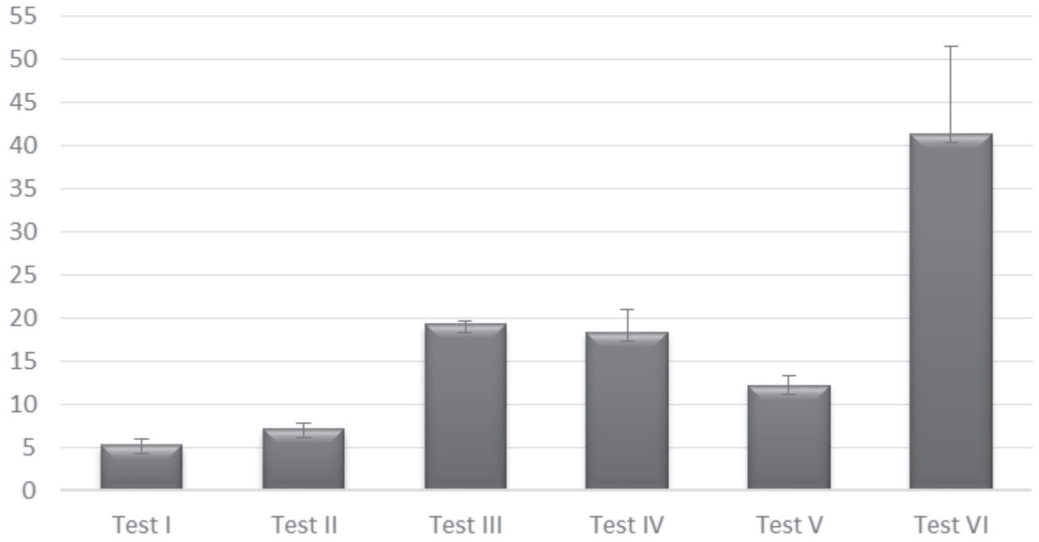

Fig. 8. Summary of average results for absorbability tests for Material A with predominant waste: sewage sludge.

flotation wastes and waste glass. The mechanism of operation during thermal processing was also known.

The new material obtained in the recycling process was subjected to tests of strength and absorbability checking whether it is suitable for use as a building aggregate. The results of the tests of waste aggregates are presented in Figs 7, 8, 9, 10, 11, 12.

The data on Material A (with sewage sludge) concerning compressive strength and absorbability, presented in figures 7,8 , prove that the additives that burn as a result of heating in the furnace cause the formation of pores in the sinter to decrease their compressive strength and specific gravity and increase their porosity. These additives also reduce the compressive strength more than three times with a $50 \%$ content. For the same samples, however, absorbability increased almost eight times. In the course of further research, the aim should be to reduce the compression strength less and at the same time increase the porosity of the sinter which would make it possible to obtain a material with the characteristics of lightweight aggregate used for the production of lightweight concretes with good compression strength. The analysis of the obtained results leads to the conclusion that the conducted research proves that it is possible to obtain lightweight ceramic aggregate based on clay and additives increasing porosity containing carbon in the elemental and organic form.

The data on Material B (with a mineral fraction) concerning compressive strength and absorbability, presented in Figs 9, 10, prove that the additives that burn as a result of heating in the furnace cause the formation of pores in the sinter, lowering their compressive strength and specific gravity and increasing their porosity, too. These additives have also more than doubled their compressive strength at 50\% content. However, it is very interesting that for the same samples the absorbability has also doubled. This shows that there is little organic matter in the waste mineral fraction. The lowest absorbability value was obtained for sample 6 containing the most post-flotation waste, which was the main supplier of coal as a captivating factor. This leads to the important conclusion that a mineral fraction can be added to clay if it contains 


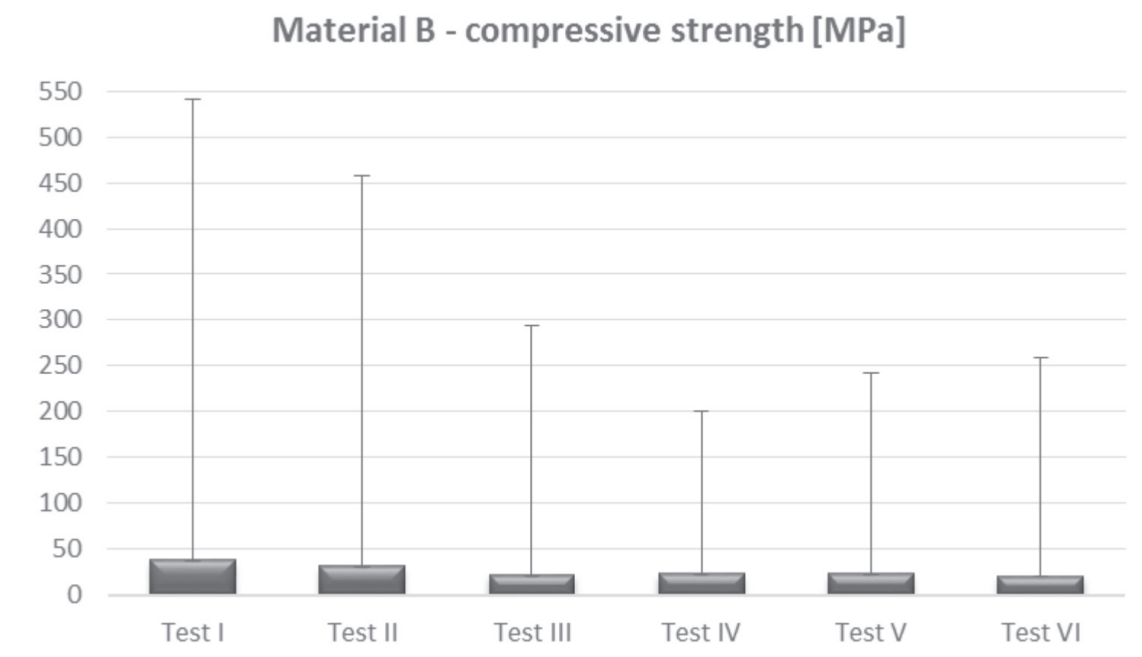

Fig. 9. Summary of average results for strength tests for Material B with predominant waste: mineral fraction.

\section{Material B - water absorption [\%]}

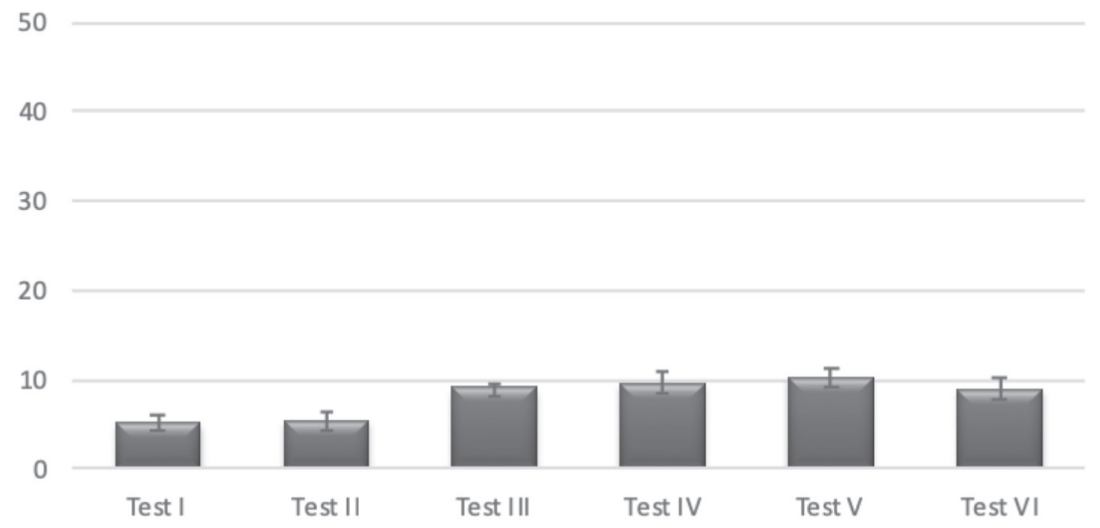

Fig. 10. Summary of average results for absorbability tests for Material B with predominant waste: mineral fraction.

enough organic matter. In the course of further research the aim should be to reduce the compression strength less and at the same time increase the porosity of the sinter which would make it possible to obtain a material with the characteristics of lightweight aggregate used for the production of lightweight concretes with good compression strength. The analysis of the obtained results leads to the conclusion that the conducted research proves that it is possible to obtain lightweight ceramic aggregate based on clay and additives increasing porosity containing carbon in the elemental and organic form.

The results of tests for Material C (with stabilizer after mechanical and biological processing), presented in Figs 11, 12, showed problems encountered during stabilizer management -such as heterogeneity and lack of homogeneity. The conducted research revealed the stabilizer's ability to change during thermal treatment (separately and with other admixtures). This gives a new opportunity to adapt the product for its subsequent use as a building material using the stabilizer. Using research data, economic and environmental benefits can be achieved through the appropriate management of the product. This will indicate a certain way of handling the stabilizer from mechanical and biological treatment of waste, both from an environmental point of view and will also contribute to saving money that was spent on sewage sludge disposal.

Summarizing the preliminary studies of the obtained Materials (A, B, C) had an average bulk density in the loose state of $658-728 \mathrm{~kg} / \mathrm{m}^{3}$, such a low bulk density not exceeding $1200 \mathrm{~kg} / \mathrm{m} 3$ is characterized by leucocyte [42]. The materials obtained in accordance with the standard [43] fall within the compression strength classes $0 \mathrm{~d} 5$ to 30 . From the strength and absorbability tests of Material A with sewage sludge and Material $\mathrm{C}$ with stabilizer (MBP), that the addition of these wastes above $20 \%$ significantly deteriorates the material properties and causes an increase in 


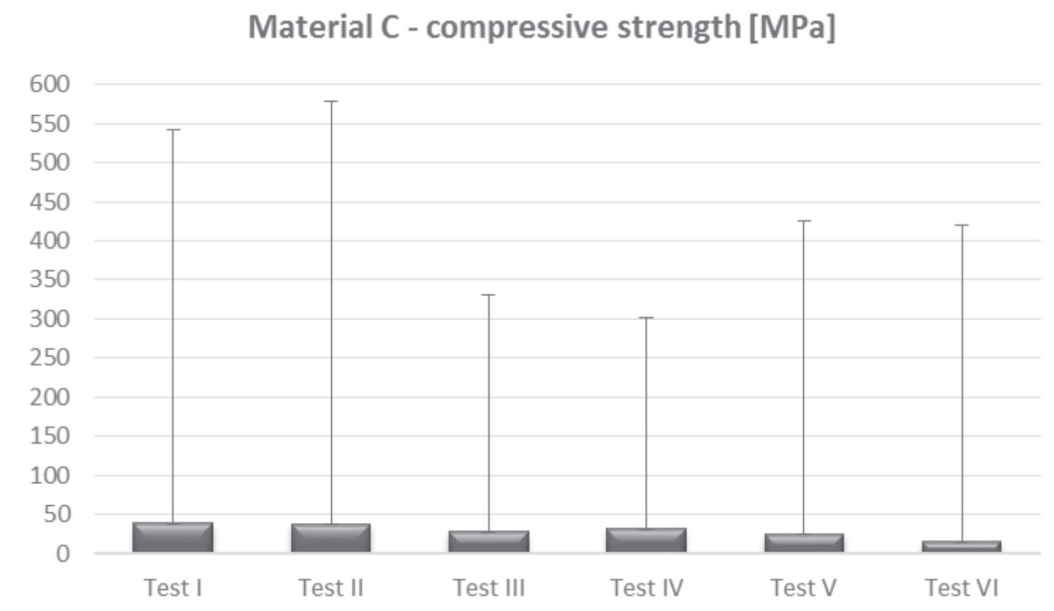

Fig. 11. Summary of mean results of strength tests for Material $\mathrm{C}$ with predominant waste: stabilizer after mechanical-biological processing (MBP).

Material C - water absorption [\%]

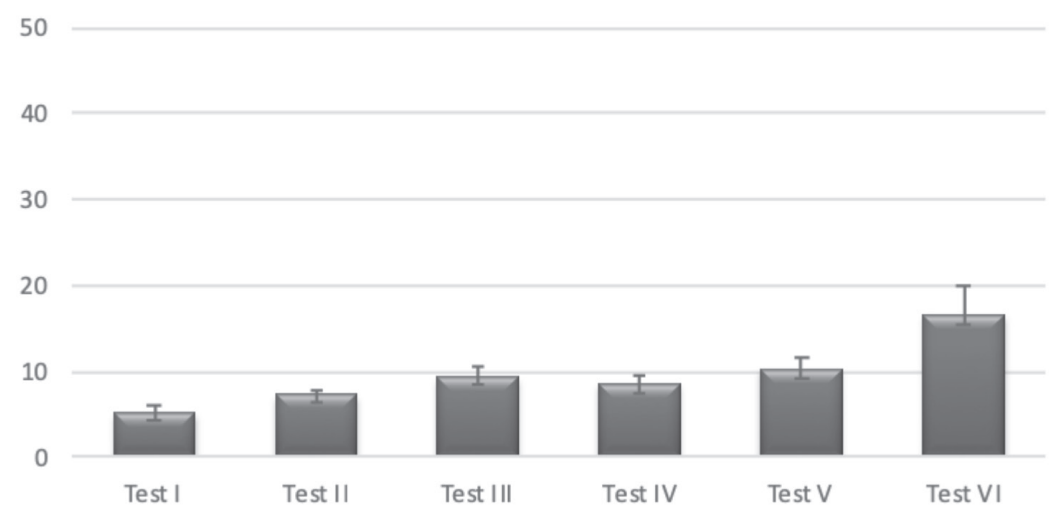

Fig. 12. Summary of mean results of absorbability tests for Material C with predominant waste: stabilizer after mechanical-biological processing (MBP).

absorbability, the results obtained for these materials are consistent with the results of research on this type of materials from the literature review [22-26, 44-46]. According to the study, Material 2 with the mineral fraction of municipal waste $<10 \mathrm{~mm}$ turns out to be the most stable and resistant to crushing with low absorbency.

\section{Conclusions}

1. The implemented closed-loop economy poses new challenges in the management of waste streams, the possibility to use them as much as possible and to reduce storage. Among the waste groups, where the EU indicates the directions of management, the greatest potential is observed for the groups of mining waste, municipal waste and sewage sludge.

2. Sewage sludge, stabilizer after mechanical and biological treatment and mineral fraction can be used for production of light building materials. The presented results of research and analysis indicate the possibility of creating new products. The presented studies indicate a good direction of use; however, the studies require further research to find appropriate proportions of mixtures.

3. It is proposed to increase the scope of further research on the obtained material in terms of thermal conductivity and leachability.

4. Preliminary research on "new" recycling creation of new building materials from problematic waste: sewage sludge, mineral fraction $<10 \mathrm{~mm}$ of municipal waste, stabilizer (MBP), post-flotation waste are in accordance with the current concepts of "zero waste" and maximum recycling.

\section{Conflict of Interest}

The authors declare no conflict of interest. 


\section{References}

1. EU Circular Economy Action Plan. Available online: https://ec.europa.eu/environment/circular-economy/ (Accessed: 23.02.2020)

2. Expert opinion, which will constitute the base material for the development of a strategy for the treatment of municipal sewage sludge for 2014-2020 Częstochowa, Poland, unpublished document, 2014.

3. BALCERZAK W., GENEROWICZ A., MUCHA Z., Application of Multi-Criteria Analysis for Selection of a Reclamation Method for a Hazardous Waste Landfill, Polish Journal of Environmental Studies, 23 (3), 983, 2014.

4. STAROSTKA-PATYK M., Environmental Approach to Managing Defective Products and Waste in the Household Appliances Industry, Polish Journal of Environmental Studies, 28 (5), 3439, 2019.

5. Regulation of the Minister of Climate of 2 January 2020 on waste catalogue (Dz.U.2020.10)

6. KOSBUCKI P., CHMARZYŃKI A., BUSZEWSKI B., Sewage Sludge Composting, Polish Journal of Environmental Studies, 9 (4), 243, 2000.

7. SMITH S.R., Agricultural recycling of sewage sludge and the environment, (book) UK, 382, 1995.

8. The Waste Act of December 12, 2012 as amended (Dz.U. z 2013 r. poz. 21).

9. WILK M., GWOREK B., Heavy metals in sewage sludge, Ochrona Środowiska i Zasobów Naturalnych 39, 40, 2009.

10. POHORELY M., SVOBODA K., TMKA O., BAXTER D., HARTMAN M., Gaseous emissions from the fluidizedbed incineration of sewage sludge. Chemical Papers 59 (6b), 458, 2005.

11. MENÉNDEZ J.A., INGUANZO M., PIS J.J., Microwaveinduced pyrolysis of sewage sludge, Water Research, 36 (13), 3261, 2002

12. FYTILI D., ZABANIOTOU A., "Utilization of sewage sludge in EU application of old and new methods--A review," Renewable and Sustainable Energy Reviews, Elsevier, 12 (1), 116, 2008.

13. Polish Geological Institute. Mining waste. Available online: http://geoportal.pgi.gov.pl/odpady/wytwarzanie (Accessed: 17.02.2020).

14. Regulation of the Minister of the Environment of 11 May 2015 on waste recovery outside installations and equipment (Dz.U. 2015, item 796).

15. ŁUSZCZKIEWICZ A., Concepts of the use of flotation waste from copper ore processing in the Legnica-Głogów region. Mineral Engineering: 1 (1), 25, 2000.

16. BIAŁOWIEC A., WOJNOWSKA-BARYŁA I., Mechanical-biological waste treatment - technological conditions. Municipal Review 2, 32, 2012.

17. SNIADECKA N., TONDERSKI A., Mineral matter in municipal solid waste. Physicochemical Problems of Mineral Processing 52 (2), 973, 2016.

18. MERINO I., ARÉVALO F.L., ROMERO F., Preparation and characterization of ceramic products by thermal treatment of sewage sludge ashes mixed with different additives. Waste Management 27 (12), 1829, 2007.

19. RAVINDRA K., DHIR OBE., JORGE DE BRITO, GURMEL S. GHATAORA, CHAO QUN LYE, 9 - Use of Glass Cullet in Ceramics and Other Applications, Sustainable Construction Materials, 167, 327, 2018.

20. WANG X., JIN Y., WANG Z., NIE Y., HUANG Q., WANG Q., Development of lightweight aggregate from dry sewage sludge and coal ash. Waste Management, 29 (4), 1330, 2009.

21. MAZELA A., UZUNOW E., Lightweight artificial aggregate from sewage sludge. Ekopartner 3 (209), 14, 2009.

22. JORDÁN M.M., ALMENDRO-CANDEL M.B. ROMERO M., RICÓN J.M.A., Application of sewage sludge in the manufacturing of ceramic tile bodies, Applied Clay Science, 30 (3-4), 219, 2005.

23. LIEW A.G., IDRIS A., SAMAD A.A., NOOR M.J.M.M., BAKI A.M., Incorporation of sewage sludge in clay brick and its characterization, Waste Management and Research, 22, 226, 2004.

24. ESMERAY E., ATIS M., Utilization of sewage sludge, oven slag and fly ash in clay brick production, Construction and Building Materials, 194, 110, 2019.

25. LATOSIŃSKA J., ŻYGADŁO M., Simultaneous recovery of matter and energy from sewage sludge in the production of sintered materials, Archives of Waste Management and Environmental Procection 11 (4), 37, 2009.

26. KUKIELSKA D., UZUNOW E., Wytwarzanie materiałów budowlanych - sposób na zagospodarowanie osadów ściekowych, Kruszywa 4, 24, 2011.

27. Synthetic aluminum silicate aggregates (European invention $\mathrm{nr}$ EP 1.841.708).

28. Production of structural building elements (European invention nr EP 1.571.135).

29. Production of foamed aggregates (patent USA nr 4.943.233).

30. Production of lightweight aggregates (patent USA nr 6.183.242).

31. WÓJCIK M., BĄK Ł., STACHOWICZ F. Unconventional Materials from Sewage Sludge with a Potential Application in a Road Construction, Advances in Science and Technology Research Journal, 12 (4), 65, 2018.

32. HAIYING Z., YOUCAI Z., JINGYU Q., Utilization of municipal solid waste incineration (MSWI) fly ash in ceramic brick: Product characterization and environmental toxicity. Waste Management 31 (2), 331, 2011.

33. ZENGA L., SUNA H., PENGA T., ZHENGA W Preparation of porous glass-ceramics from coal fly ash and asbestos tailings by high-temperature pore-forming, Waste Management, 106 (1), 184, 2020.

34. FIALA L., KONRÁD P., FORT J., KEPPERT M., CERNÝ R., Application of ceramic waste in brick blocks with enhanced acoustic properties, Journal of Cleaner Production, 261, Article 121185, 2020.

35. MAHIEUX P-Y., AUBERT J-E., CYR M., COUTAND M., HUSSON B., Quantitative mineralogical composition of complex mineral wastes - Contribution of the Rietveld method. Waste Management, 30 (3), 378, 2010.

36. GRONBA A., BIAŁOPIOTROWICZ T., GRĄZ K., NOWAK J. The use of sewage sludge for the production of lightweight aggregates. In: Marczewska B (ed) Municipal economy new solutions and technologies. SeidelPrzywecki, Warszawa, 63, 2015.

37. POLISH GEOLOGICAL INSTITUTE sheet Nisko 890. Warszawa, 8, 2007.

38. PN-75/C-04616/01 Water and sewage special tests. Determination of water content, dry matter, organic substances and mineral substances in municipal sewage sludge.

39. PN-93/ Z-15006 Solid municipal waste. Determination of morphological composition. 
40. BN-87/9103-03 Urban waste treatment - Collection, storage and transmission as well as initial preparation of waste samples for testing.

41. KOT M., Research on new possibilities of using the mineral fraction of municipal waste, The John Paul II Catholic University of Lublin, Stalowa Wola, 2017.

42. FRANUS M., BANDURA L., Properties of lightweight aggregates modified with used mineral sorbents, Construction and Architecture 13 (2), 73, 2014.

43. PN-EN 711-1+A1:2015-10/Ap1 Specification for masonry units - Part 1: Clay masonry units.

44. GASKA K., GENEROWICZ A., ZIMOCH I., CIUŁA J., SIEDLARZ D., A GIS based graph oriented algorithmic model for poly-optimization of waste management system. Architecture Civil Engineering Environment, 11 (4), 151, 2018.

45. CZOP M., Characteristics of selected fuels from wastes in respect to their energetic use. Przemysł Chemiczny, 96 (8), 1666, 2017.

46. SMOL M., The importance of sustainable phosphorus management in the circular economy (CE) model: the Polish case study. Journal of Material Cycles and Waste Management, 21 (2), 227, 2019. 